\title{
Publication Ethics and Publication Malpractice Statement
}

All editors, reviewers and authors, should be familiarized and take into account the Publication Ethics and Publication Malpractice Statement of the international journal "Semiconductor Physics, Quantum Electronics and Optoelectronics". This statement is based on the COPE Code of Conduct for Journal Editors.

One of the important responsibilities of our journal is to maintain the highest ethical standards. Publication of an article in a peer-reviewed journal is an essential model for our journal. It is necessary to agree with standards of expected ethical behavior for all parties involved in the act of publishing: the journal editor, the reviewer, the author and the publisher.

\section{For editors:}

The editors of the journal are responsible for deciding which of the articles submitted to the journal should be published. In evaluating the submitted works, the editors should limit themselves only to the intellectual content. The editor may be guided by the policies of the journal's editorial board and constrained by such legal requirements as shall then be in force regarding libel, copyright infringement and plagiarism. The editor may confer with other editors or reviewers in making this decision. The editors must ensure the confidentiality of the submitted works until they are published, except in the case of suspicion of double submission. In case the editors decide not to publish a material, the manuscript should not be used for other purposes without the express written consent of the author. The editor of a submitted manuscript must not have a stake in the authors.

The editor and any editorial staff must not disclose any information about a submitted manuscript to anyone other than the corresponding author, reviewers, potential reviewers, other editorial advisers, and the publisher, as appropriate. Unpublished materials disclosed in a submitted manuscript must not be used in an editor's own research without the express written consent of the author.

\section{For reviewers:}

The reviewers of the journal assist the editors in taking the decision of publishing a submitted manuscript. The reviewers are bound to treat the manuscript received for peer reviewing as confidential, and must not use the information obtained through peer review for personal advantage. They must not be shown to or discussed with others except as authorized by the editor. The reviewers should not consider manuscripts in which they have conflicts of interest with any of the authors, companies, or institutions connected to the papers. Reviewers should not consider manuscripts in which they have conflicts of interest resulting from competitive, collaborative, or other relationships or connections with any of the authors, companies, or institutions connected to the papers. Privileged information or ideas obtained through peer review must be kept confidential and not used for personal advantage.

\section{For authors:}

Authors of reports of original research should present an accurate account of the work performed as well as an objective discussion of its significance. Underlying data should be represented accurately in the paper. A paper should contain sufficient detail and references to permit others to replicate the work. Fraudulent or knowingly inaccurate statements constitute unethical behavior and are unacceptable.

By submitting a manuscript to this journal, the author(s) warrant that the manuscript is their own, original work and that it has neither been published previously nor is currently being considered for publication elsewhere. They also warrant that the sources of any ideas and/or words in the manuscript that are not their own have been properly attributed through appropriate citations and/or quotes.

An author should not in general publish manuscripts describing essentially the same research in more than one journal or primary publication. Submitting the same manuscript to more than one journal concurrently constitutes unethical publishing behavior and is unacceptable. Proper acknowledgment of the work of others must always be given. Authors should cite publications that have been influential in determining the nature of the reported work.

Authorship should be limited to those who have made a significant contribution to the conception, design, execution, or interpretation of the reported study. All those who have made significant contributions should be listed as coauthors. Where there are others who have participated in certain substantive aspects of the research project, they should be acknowledged or listed as contributors. The corresponding author should ensure that all appropriate coauthors and no inappropriate co-authors are included on the paper, and that all co-authors have seen and approved the final version of the paper and have agreed to its submission for publication. Where the manuscript reports on commercial software, hardware, or other products, authors must include a declaration at the beginning of the manuscript in which they must either state that no conflict of interest exists or describe the nature of any potential conflict. All sources of financial support for the research should also be disclosed in the manuscript.

When an author discovers a significant error or inaccuracy in his/her own published work, it is the author obligation to promptly notify the journal editor or publisher and cooperate with the editor to retract or correct the paper. 